Please do not remove this page

RMIT

UNIVERSITY

\title{
Aspects of spirituality in adolescents
}

Bussing, Arndt; Foller-Mancini, Alex; Gidley, Jennifer; Heusser, Peter

https://researchrepository.rmit.edu.au/esploro/outputs/9921864279601341/filesAndLinks?institution=61RMIT_INST\&index=null

Bussing, A., Foller-Mancini, A., Gidley, J., \& Heusser, P. (2010). Aspects of spirituality in adolescents. International Journal of Children's Spirituality, 15(1), 25-44. https://doi.org/10.1080/13644360903565524

Document Version: Submitted Version

Published Version: https://doi.org/10.1080/13644360903565524

Repository homepage: https://researchrepository.rmit.edu.au

(C) Taylor and Francis

Downloaded On 2023/04/27 00:51:07 +1000

Please do not remove this page 


\title{
Published as:
}

Bussing, A. Foller-Mancini, A. Gidley, J. and Heusser, P. 2010, 'Aspects of Spirituality in Adolescents', in International Journal of Children's Spirituality, Routledge, Oxford, UK, vol. 15, no. 1, pp. 25-44 ISSN: $1364436 \mathrm{X}$

\section{Aspects of Spirituality in Adolescents}

\section{Arndt Büssing ${ }^{1 *}$, Axel Föller-Mancini ${ }^{1,2}$, Jennifer Gidley, ${ }^{3}$ Peter Heusser ${ }^{1}$}

1 Centre for Integrative Medicine, Chair of Theory in Medicine, Integrative and Anthroposophic Medicine, Research Group Spirituality and Coping, Faculty of Medicine, University Witten/Herdecke, Germany

${ }^{2}$ Alanus University of Arts and Social Sciences, Faculty of Education, Germany

${ }^{3}$ Global Cities Research Institute, RMIT University, Melbourne, Australia

*Corresponding author:

Prof. Dr. med. Arndt Büssing

University Witten/Herdecke

Gerhard-Kienle-Weg 4; 58313 Herdecke, Germany

phone: +49-2330-623246; fax: +49-2330-623358

e-mail: arndt.buessing@uni-wh.de

\begin{abstract}
:
This paper analyses which aspects of spirituality are valued by adolescents, and how they are interconnected with youths' life satisfaction and 'selfcenteredness'. The participants were 254 adolescents $\left(11^{\text {th }}\right.$ grade) of four different high-schools from West-Germany. After re-validation of the 6-factorial student's version of the ASP questionnaire (ASP-S, Cronbach's alpha $=.90$ ), we found that they appreciated most Conscious interactions, Compassion / Generosity and Aspiring for Beauty / Wisdom, while particularly Religious orientation Prayer (Trust in God), esoteric Transcendence conviction, or Quest orientation were of lower relevance. The importance of these aspects of spirituality is known to increase with higher age. The correlation pattern between aspects of spirituality and life satisfaction dimensions differed remarkably between female and male adolescents. In particular Conscious interactions correlated with future prospects in females, while in males it correlated much better with family life and school situation. It became obvious that the non-formal aspects of spirituality in terms of relational consciousness are still vital, particularly secular humanism (i.e., Conscious interactions, Compassion / Generosity). These findings may have implications for religious educational programs
\end{abstract}

Keywords: adolescents, spirituality, gender, consciousness, self-centeredness, mutual consideration 


\section{Introduction}

During the transitional process of adolescence, which involves biological and psychological changes, the traditional norms are cognitively questioned, and external authority is rejected. Adolescents recognize that their parents are not as perfect as assumed, that society's ethical/moral demands are often hypocritical, that the economy is interested only in profit (people are needed merely as consumers), humanity seems to have lost all virtue in the light of the cruelty of past wars. In addition they have learned that there is no scientific evidence for the existence of an omnipresent helping God who will solve mankind's problems when asked for in devoted prayers. Consequently adolescents may turn away from their childhood spirituality with its strong magical and emotional fabric. Many do assume that "religious belief is irrational, out of date, nonsensical" (Hay \& Nye, 2006). Young people are in a process of unknown identity, social role, unclear future perspective, and moral purpose. Youth futures researchers have linked this loss of meaning and purpose to the contemporary secular societal context in which young people do sense a spiritual vacuum in their society (Gidley, 2005). They have to test limits, become autonomous, and find identity and a sense of self. In fact, one can state a significant decline of role models in adolescents since the nineteen-fifties (Zinnecker, 1986). During this phase of adolescence they may return to egocentric thoughts of 'self-centeredness'.

The current era of social insecurity due to several unsolved problems and unmet promises may lead to unrestricted autonomy as social norms seem to become less important. An 'Ego-centred' attitude tends to predominate, as conceptualized by hedonism (i.e., pleasure has an ultimate importance), eudemonism (i.e., happiness as an ultimate importance), and utilitarianism (i.e., the moral worth of an action is determined solely by its contribution to overall utility, for example, to happiness or pleasure). Apart from this one may find cultural forms of expression among youths which create perceptions of happiness by aestheticalexpressive practices such as dancing contests or athletic challenges. Thrilling experiences are in most cases gained only by excessive training or confrontation with extreme situations.

Some authors regard this as an urge for 'borderline experiences' of the Mystical, the Arcane or even the touch of death (Helsper et al., 2007). Perhaps young people are seeking to initiate themselves in the absence of appropriate enculturation practices? It has been suggested that if a society, or the responsible adults, do not provide some adequate initiation or orientation for adolescents one of two things may happen (Gidley, 2002):

- they may seek to initiate themselves through drugs, and other customs referred to as part of 'youth sub-culture' - dress, body mutilation, 'street living' and even risk-taking behaviors.

- they may become disorientated, lose their sense of meaning, or hope about the future, or at worst attempt to take their own lives.

For many teenagers, conventional ethical standards are of arguable importance. In fact, as stated by Ziebertz (Ziebertz, 2006), "young people are born intro a situation where plurality is normal and where existing values, convictions and life styles are no longer attributable to a single world view". This means that the former ecclesiastic interpretations (which are often paternalistic) of personal life planning and underlying ethics become more and more irrelevant, particularly because "adolescents typically develop very critical attitudes towards traditional worldviews" (Ziebertz, 2006). The consequences can be ethical and social indifference (or moral relativism). A 'Me Foremost' attitude of self-dependence might be the consequence of neo-liberal social Darwinism, while humanity as a value, an ideal or a mission seems to lose its importance among the general principles of western societies (Büssing, 2006a). Confronted with strong leading principles ('meta-narratives'), youths may absorb the scepticism of early post-modernism and transform their spiritual orientation to a non-verbal level. Buschmann regards distinct music styles highly popular among adolescents (i.e., 
techno, hip hop, metal etc) as an expression of 'secular religiosity' (Buschmann, 2001). It remains to be shown whether or not and or how this 'myth without words' (Koenot, 1997) interacts with the ethical and social awareness of adolescents. It will also be interesting to see how the new rational discourses on spirituality in continental and anglo-philosophies will filter down to young people's attitudes (Molz \& Gidley, 2008).

But what exactly is spirituality? Although there are multiple definitions, there is no general consensus, because all definitions are true and practicable for the respective disciplines (i.e., theology, sociology, psychology, education, esoteric studies, alternative health systems etc.). Tanyi globally defined spirituality as humans' search for meaning in life, while religion involves an organized entity with rituals and practices about a higher power or God (Tanyi, 2002). Underwood and Teresi described spirituality as an individual and open approach in the search for meaning and purpose in life, as a search for 'transcendental truth' which may include a sense of connectedness with others, nature, and/or the divine, and that "spirituality can call us beyond self to concern and compassion for others" (Underwood \& Teresi, 2002). Among the cluster of spirituality values that emerged from English students (aged between 12 and 18) one may find beliefs, self and personal identity, religious identity, and relationship with others (Wintersgill, 2008). 'Relational consciousness' is the core motif of Hay and Nye's theoretical model of children's spirituality, which was used to describe the primal dualistic patterns of I - self, I - others, I - God etc. (Hay \& Nye, 2006). In fact, connectedness can be regarded as one of the core motifs of spirituality, with implicit attitudes of respect, compassion, and awareness.

But not all of these aspects might be of similar importance in adolescents, given the decline in institutional religiosity in Europe (Jagodzinski \& Dobbelaer, 1993), the large proportion of individuals with a lacking interest in spiritual/religious issues at all (Büssing et al., 2005a, Büssing et al., 2007a, Büssing et al., 2007b, Büssing et al., 2007c, Büssing et al., 2008, Büssing et al., 2009b), and the rejection by some of the moral implications of institutional religiosity. In an international empirical study about religiosity among young people, Ziebertz investigated German individuals and confirmed a "certain degree of secularisation" (Ziebertz, 2006). Interest in religious topics was stated by $11 \%$ of young adults (18-29 years of age), and only 10\% mentioned 'religious experiences', while at least 34\% believed in the existence of a personal God (Ziebertz, 2007). A study among German youth confirmed that just $30 \%$ believed in God and $19 \%$ in other higher powers, and about $28 \%$ are not interested in religion at all (Hurrelmann \& Albert, 2006). Thus, while the cognitive and experiential dimension of religiosity/spirituality may diverge among adolescents or young adults, it is also obvious that the relevance of institutional religiosity decreases - at least in Europe. This trend towards an increase in non-denominational forms of spirituality has also been reported in Australia (Tacey, 2003, Bouma, 2006)..

Because spirituality is an attribute of all human beings, a more open and pluralistic view rather than exclusive interpretations of distinct religious traditions is important. Albeit the multidimensional constructs spirituality and religiosity are interconnected (Büssing et al., 2005b, Büssing et al., 2007c), they are conceptually distinct. One could differentiate spirituality in religiosity, and spirituality as opposed to religiosity. In fact, spirituality is a complex and multi-dimensional issue, and can be defined as an individual and open approach in the search for meaning and purpose in life; in contrast, religion is an institutional and culturally determined approach which organizes the collective experiences of people (faith) into a closed system of beliefs and practices (Büssing et al., 2006). Of course, formal religiosity without the spiritual might be just the cladding (or doctrine), while spirituality without the religious can be too shallow. We thus conceptualized spirituality as follows (Büssing \& Ostermann, 2004, Büssing, 2006b):

„Spirituality refers to an attitude of search for meaning in life. The searching individual is aware of its divine origin (either transcendent or immanent, i.e., God, Allah, JHW, Tao, Brahman, Prajna, Unity etc.), and feels a connection with others, nature and the Divine etc. Because of this awareness one 
strives towards the realisation of the respective teachings, experiences or insight, which have a direct impact on conduct of life and ethical commitments."

This definition with its underlying motifs of search, experience of connection, realisation, and ethical conduct comprises aspects of formal religiosity and also unique and individual spiritual views.

For her work with 15-17 year of boys, Engebretson used an analytical schema through which the interviews were conducted. She defined (Engebretson, 2004):

"Spirituality is the experience of the sacred other, which is accompanied by feelings of wonder, joy, love, trust and hope. Spirituality enhances connectedness within the self, with others and with the world. Spirituality illuminates lived experience. Spirituality may be expressed in relationships, prayer, personal and communal rituals, values, service, action for justice, connection with the earth. Spirituality may be named in new and redefined ways or through the beliefs, rituals, symbols, values, stories of religious traditions".

Nevertheless, previous findings indicated that the individual concepts of spirituality are highly dependent on the contextual 'world-view', and refer to an immaterial, not sensual comprehensible truth (God, 'presence', 'powers'), which can nevertheless be experienced, and may become an orientation in life (Büssing et al., 2007b). One can differentiate an attitude of search, adoption of beliefs, and intuitive experience (Büssing et al., 2007b). Also social sciences differentiate religious knowledge, belief, experience, ritual practice/engagement, and the impact on daily life (Ziebertz, 2007).

We can assume a 'common ground' in the definitions of Engebretson (Engebretson, 2004) and ours (Büssing \& Ostermann, 2004, Büssing, 2006b) which is in line with the differentiation found in social science (Ziebertz, 2007), because several motifs are identical, i.e., experience of the sacred other / awareness of its divine origin, connectedness, and expression / realisation in life (including values, ethics, rituals etc.). With reference to this 'common ground', we analyse which aspects of spirituality are valued by adolescents, how they compare with those of adults, and how these aspects of spirituality are interconnected with youths' life satisfaction and 'self-centeredness'. To address this topic, we have used the Aspects of Spirituality (ASP) questionnaire (Büssing et al., 2007b), which differentiates and quantifies cognitive, emotional, intentional and action-oriented matters of theism/belief, pantheism/transcendence, existentialism, humanism etc. The instrument addresses formal religiosity (including organized forms of practice and rituals) and individual aspects of spirituality (including conscious interactions, existentialistic quest orientation, and cognitive transcendence convictions).

\section{Materials and Methods}

\section{Participants}

In this anonymous survey, we enrolled 254 adolescents from four different high-schools located in the same area (Dortmund, Hagen, Haltern, and Schwerte) of West-Germany. Similarly to the study by Ziebertz (Ziebertz, 2006), the survey was conducted among school pupils in the $11^{\text {th }}$ grade of the high-schools (Gymnasium, equivalent to UK "grammar school"). The respective teachers of the participating classes distributed the anonymous questionnaires. The students (and their teachers) were assured of confidentiality, gave informed consent to participate, and completed the questionnaire, which asked for neither names nor initials, by themselves. We had neither inclusion nor exclusion criteria (just the will to participate). 


\section{Measures}

To measure a wide variety of important aspects of spirituality beyond conventional conceptual boundaries, we developed a questionnaire on the basis of the answers of expert representatives of various spiritual orientations which aspects of spirituality are relevant to them (i.e., Catholics, Protestants, members of the Anthroposophic "Christengemeinschaft", Bahá' '́, Muslims, Jews, Buddhists, and atheists) (Büssing, 2006b). The identified motifs we condensed to 40 items of the original ASP questionnaire (Büssing et al., 2007b) which primarily differentiates 7 factors (Cronbach's alpha $=.94)$, i.e., Prayer, trust in God and shelter; Insight, awareness and wisdom; Transcendence conviction; Compassion, generosity and patience; Conscious interactions; Gratitude, reverence and respect; and Equanimity. For this analysis, we used a shortened version with 25 items (ASP 2.1), focusing on the main factors of the instrument (Büssing, 2010), which were tested in a pilot-study enrolling adolescents from religious courses at high school (Büssing, 2009), i.e., (1) Religious orientation: Prayer / Trust in God (religious views) (2) Search for Insight / Wisdom (philosophical/existentialistic views), (3) Conscious interactions (humanistic views) and (4) Transcendence conviction (esoteric views). The term "God" was used just one time. The marker items s32 ("I orient myself with ethical norms") and s25 ("I work honorary for others") were taken from the primary version of the instrument. All items were scored on a 5point scale from disagreement to agreement ( 0 - does not apply at all; 1 - does not truly apply; 2 - don't know; 3 - applies quite a bit; 4 - applies very much). The scores are referred to a $100 \%$ level (4 "applied very much" $=100 \%)$.

The students categorized themselves as either religious and/or spiritual with two items derived from the SpREUK manual (Büssing et al., 2005b), i.e., "I regard myself as a religious / spiritual individual". We neither provided definitions they could rely on nor did we explicitly ask how they would define spirituality/religiosity. They were completely free to ascribe themselves depending on their 'inner resonance'.

Life satisfaction was measured with the Brief Multidimensional Life Satisfaction Scale (BMLSS) (Büssing et al., 2009a) which refers to the Huebner's 'Brief Multidimensional Students' Life Satisfaction Scale' (Huebner et al., 2004, Zullig et al., 2005). The eight items of the BMLSS address intrinsic dimensions (Myself, Overall life), social dimensions (Friendships, Family life), external dimensions (School situation, Where I live), and the prospective dimension (Financial situation, Future prospects). The internal consistency of the instrument was good (Cronbach's alpha $=.87$ ) (Büssing et al., 2009a). Each item was introduced by the phrase "I would describe my satisfaction with ...", and scored on a 7-point scale from dissatisfaction to satisfaction (0 - Terrible; 1 - Unhappy; 2 - Mostly dissatisfied; 3 - Mixed (about equally satisfied and dissatisfied); 4 - Mostly satisfied; 5 - Pleased; 6 Delighted). The BMLSS sum score was referred to a 100\% level ("Delighted").

Self-centeredness was assessed with the item "Consideration for others is fine, but what really matters in the end is that I get ahead in school and my career" as tested in a pilotstudy (Büssing, 2009). We are aware that mutual consideration is socially desired and thus pupils would probably respond (cognitively) positively when asked directly; thus we chose the indirect phrase. The item was scored on a 3-point scale (disagreement, don't know, agreement).

\section{Statistical analyses}

Reliability and factorial analyses, analyses of variance (ANOVA) and correlation analyses (Spearman rho) were performed with SPSS 15.0 for Windows (SPSS GmbH Software, Munich). We considered a level of $\mathrm{p}<0.05$ as statistically significant. 


\section{Results}

\section{Demographic and behavioural results}

Among the 254 adolescents, $51 \%$ were female and 49\% male; their mean age was $16.6 \pm 0.72$ years. As shown in Table 1, significantly more male students lived with both parents as compared to girls. The number of books in the household (as an indirect marker of prosperity and valuation of culture) did not differ between both genders.

$>$ Insert Table $1<<$

Most students had a Christian denomination (59\% Catholics, 33\% Protestants), 2\% other denominations and 7\% stated none. However, 67\% regarded themselves (cognitively) as neither religious nor spiritual (R-S-), $21 \%$ as religious but not spiritual $(\mathrm{R}+\mathrm{S}-), 6 \%$ as both religious and spiritual $(\mathrm{R}+\mathrm{S}+)$, and $6 \%$ as spiritual but not religious $(\mathrm{R}-\mathrm{S}+)$. In trend, more boys than girls would regard themselves as R-S-.

The life satisfaction of adolescents was high, and did not differ between female or male students (Table 1).

With respect to self-rated behaviours, more boys than girls claimed that "Consideration for others is fine, but what really matters in the end is that I get ahead in school and my career" (self-centeredness) (Table 1).

\section{Reliability and factor analysis}

We intended to confirm the factorial structure of the ASP questionnaire, and first combined the data of 254 adolescents with those of 988 healthy adults (52\% women; mean age: $43.2 \pm$ 15.5 ; $80 \%$ Christian denomination; $68 \%$ living with a partner; $80 \%$ high school education) derived from an already existing data pool (Büssing, 2010). As shown in Table 2, the 25-item instrument had a very good internal consistency $($ Cronbach's alpha $=.94)$. The item difficulty index (mean value / 4) was .67; with the exception of four items with ceiling effects (s11, s22, $\mathrm{s} 23, \mathrm{~s} 28)$, all item were in the acceptable range of 0.2 to 0.8 . Factor analysis confirmed 4 factors which would explain $64.6 \%$ of variance:

1. Religious orientation (Prayer / Trust in God) (alpha $=.93$; mainly action [including private prayers instead of congregational practice] and emotion),

2. Search for Insight / Wisdom (alpha = .88; action and intention),

3. Conscious interactions (alpha $=.83$; action and intention),

4. Transcendence conviction (alpha $=.85$; cognitive items).

$>$ Insert Table $2<<$

As shown in Figure 1, the respective aspects of spirituality of adolescents were significantly lower as compared to adults $(\mathrm{p}<.0001)$.

$$
>>\text { Insert Figure } 1<<
$$

Next we performed reliability and factor analyses with the data sets of adolescents only. With Cronbach's alpha $=.90$, the internal consistency of the whole scale remained very good. The item difficulty index of the instrument was .50; with the exception of item s37 (reading religious/spiritual books) which had a bottom effect, all items were in the acceptable range of 0.2 to 0.8 . However, factor analysis pointed to a 6 -factorial structure with 3 main factors (eigenvalues $>2$ ), and 3 minor factors (eigenvalues between 1 and 2). Two scales remained unchanged, i.e., Religious orientation (Prayer / Trust in God) (alpha = .88) and Transcendence Conviction (alpha $=.70$ ), while the Conscious interaction items s21, s22 and $23($ alpha $=.75)$ would diverge from Compassion/Generosity items s28 and s26 (alpha $=.63)$; 
also the scale Search for Insight / Wisdom would diverge in two sub-constructs with items s10, s11, s12, s13 on the one hand (Aspiring Beauty / Insight; alpha = .76), and items s14, s15, s16 on the other hand (Quest orientation; alpha $=.76$ ).

Because the ASP questionnaire (version 2.1) exhibited very good internal consistency both in the whole sample as well as in the adolescents' sample, it can be used in longitudinal studies to asses the development of distinct aspects of spirituality during the course of life. To make the results comparable with those of adults, we decided to present data of the 4 main factors of the ASP (version 2.1) confirmed in the large sample, and to specify the data with the respective sub-scales (ASP-S [students] version) for detail analyses in adolescents.

\section{Aspects of spirituality in adolescents}

The adolescents in the study had the highest scores on Conscious interactions (both subscales), while their lowest scores were for Prayer / Trust in God and Transcendence conviction. In contrast, Search for Insight / Wisdom reached intermediate scores, particularly the more existentialistic sub-scale Quest orientation, while the subscale Aspiring Beauty / Wisdom was valued high (Table 3). The marker item "I orient myself with ethical norms" was agreed by $22 \%$ of the students and rejected by $38 \%$ ( $40 \%$ were not sure).

$$
>>\text { Insert Table } 3<<
$$

Female students had significantly higher scores than male students with respect to Conscious interactions (both subscales) and Prayer / Trust in God, while neither Search for Insight / Wisdom (both subscales) nor Transcendence conviction significantly differed (Table 3). Moreover, there were no significant differences with respect to Catholics or Protestants or family status (i.e., living with both parents, one parent, others) (data not shown).

With respect to their religious/spiritual self categorization, Religious orientation (Prayer / Trust in God) and Conscious interactions (both subscales) were the highest in $\mathrm{R}+\mathrm{S}+$ students, while Search for Insight / Wisdom (both subscales) and Transcendence conviction were the highest in both $\mathrm{R}-\mathrm{S}+$ and $\mathrm{R}+\mathrm{S}+$, indicating that the spiritual attitude (which was defined by the students themselves) was of relevance for these aspects of spirituality. However, R-S- adolescents had significantly lower scores, even in those aspects without an explicit religious or esoteric connotation (Table 3).

\section{Engagement in private prayer and voluntary work for others}

With respect to praying, $48 \%$ of girls were praying for others ( $47 \%$ did not) as compared to $30 \%$ of boys $(64 \%$ did not). This difference was statistically significant $(\mathrm{p}<.0001 ;$ Chi2). Also praying for themselves differed significantly $(\mathrm{p}<.015)$ : $32 \%$ of girls were praying for themselves ( $43 \%$ did not) as compared to $28 \%$ of boys ( $62 \%$ did not). Thus, the proportion of students engaged in private non-institutional prayer was similar to that of students with an emotional trust in and turning to God (s03) as stated by female and male students (31\% of girls versus $22 \%$ of boys).

Voluntary work for others was stated by $41 \%$ of girls ( $45 \%$ did not) and $36 \%$ of boys (56\% did not). These differences were statistically not significant $(p=.26)$.

\section{Associations between aspects of spirituality and life satisfaction in adolescents}

Because one may assume that a spiritual attitude is associated with higher life satisfaction, we performed correlation analyses. As shown in Table 4, there were weak to moderate intercorrelations between the aspects of spirituality except for the Conscious interaction subscale which did not significantly correlate with either of the two subscales Search for Insight / Wisdom. 
The correlation pattern between aspects of spirituality and the life satisfaction dimension differed remarkably in most of the factors between female and male adolescents (Table 5). Although the Conscious interactions subscale was moderately associated with future prospects and school satisfaction in both males and females, in males Conscious interactions correlated much better with family life and school situation, while particularly family life was not significantly associated in female students. Moreover, satisfaction with living area was interconnected with Conscious interactions in boys, but not in girls. While the Quest orientation was associated with none of the life satisfaction dimensions in males, it was moderately negatively associated with self and overall life in females. Satisfaction with future prospects was significantly associated with Aspiring for Beauty / Insight in males, but not in females. Moreover, 'self-centeredness' was negatively associated with Transcendence conviction in male students, but not in female students (Table 5). Neither Religious orientation, Transcendence conviction nor Compassion / Generosity were significantly associated with life satisfaction dimensions in girls or boys (Table 5).

$$
>\text { Insert Table } 5<<
$$

\section{Discussion}

In our study with 16-17 year old high school students, we found that they most appreciated secular humanistic attitudes such as Conscious interactions (with their sub-dimensions Conscious interactions and Compassion / Generosity) and Aspiring for Beauty / Wisdom, while of lower relevance were Religious orientation (Prayer / Trust in God), esoteric Transcendence conviction, or existentialistic/philosophic Quest orientation. As shown in Figure 1, the relevance of these aspects of spirituality was much higher in elderly. This could indicate a response shift due to life experience, change of values and priorities. It is remarkable that the adolescents investigated were predominantly 'religious sceptics' $(67 \% \mathrm{R}-$ $\mathrm{S}-$ and $6 \% \mathrm{R}-\mathrm{S}+$ ). We would interpret our findings that the investigated adolescents are either undecided (because they had no concrete religious experience so far) or in fact they are not (yet) interested in religious issues because they encounter more concrete struggles in relationships, family life, pressure to perform, anxiety about their future, etc. However, one has to discuss the possibility that their 'spirituality' is masked by a lack of adequate language. To overcome this, we addressed different aspects of spirituality, and found that the dimensions within the context of secular humanism are much more important to them as compared to topics of conventional religious orientation and praying. In fact, both aspects are only weakly interconnected.

Our findings are nevertheless in contrast with those of Engebretson that among Australian 14 year old boys different religiosity/spirituality indicators were highly expressed (Engebretson, 2002). For example, 83.5\% indicated that they sometimes or often "spend time in praying and/or quite thought", while in our study only $28-48 \%$ were praying either for others or themselves. One explanation could be that in the Australian study active praying and passive moments of quietness were addressed in one item, which is problematic from a methodological point of view. On the other hand, it is striking that $60 \%$ of the boys believe in a loving God who cared about them - but the 14 year old students were recruited exclusively in Catholic schools, while we enrolled 16-17 year old students from different schools (2 communal, 1 Steiner school, and 1 Catholic school). When differentiated with respect to the school form, we found significantly higher scores even for Religious orientation (Prayer / Trust in God) particularly in the Catholic school ( $\mathrm{F}=7.5 ; \mathrm{p}<0.0001)$.

It is notable that female adolescents appreciated Conscious interactions (particularly the sub-construct Compassion / Generosity) significantly higher than male adolescents. However, in male students, Conscious interactions were associated with family life and where 
they live, an association which was not observed in girls. This may mean that for boys a secure and supportive family background was of high relevance (and probably also extrafamiliar groups) to interact consciously with others, self and environment, while for girls the satisfaction with themselves was of more relevance. Nevertheless, future prospects and school satisfaction were of importance for boys and girls, too, which is an important finding in itself.

It was evident that male adolescents have significantly lower scores with respect to Compassion / Generosity which was highly valued by girls. In line with this, more male students than females had an attitude of self-interest and rejected mutual consideration for others; similarly, praying for others was reported more frequently in girls than in boys. We currently can not exclude the possibility that boys may develop much later this attitude of mutual consideration which seems to be expressed earlier in girls. Findings of Engebretson enrolling Australian male teenagers indicate that "the dominance of personal integrity/relationship values in boys' responses suggests that a key component of their spirituality is a growing tendency to challenge the hegemonic ideal masculinity, and to look towards a future where masculinity is defined in more varied and fulfilling ways" (Engebretson, 2006). Thus, teachers should particularly support and encourage boys during childhood and adolescence to develop as responsible and considerate individuals. Whether the encouraged positive intentions are really put into practice remains to be shown.

The findings of a preceding pilot study (Büssing, 2009) that most adolescents (cognitively) regarded themselves as neither religious nor spiritual were confirmed in this larger study. When asked about their perceived (emotional) God images, $42 \%$ indicate positive perceptions (i.e., Happiness was mentioned by $28 \%$, Love by $27 \%$, Affection by $25 \%$, Security by $39 \%$, and Shelter by $42 \%$ ), and Disinterest by $30 \%$ (Büssing, 2009)). The cognitive and emotional substructure of adolescents' spirituality may strongly differ. Emotionally there seems to be a longing to be sheltered, guided, and beloved by an external transcendental being providing meaning and direction in a complicated life (Büssing, 2009). On the other hand, they do know that there is no scientific evidence for the existence of higher beings (i.e., God), and thus it is not surprising that most will (cognitively) state they are neither religious nor spiritual, that they are disinterested in God - and therefore they have low scores for Religious orientation. Nevertheless, during the phase of adolescence represented herein (16-17 years of age), the conscious and caring aspects of secular humanism (Conscious interactions), and the intention to be generous and compassionate were of relevance - but such intentions are not necessarily followed by actions.

To rely on the conceptual background, Ziebertz (Ziebertz, 2006) found that the religious world views of German adolescents are mainly Pragmatism (i.e., only the human being can give meaning and sense in life), Universalism, Metatheism, Naturalism and Agnosticism, while Christian, Critical and Atheistic were rejected. Another study found that religious pluralism was of highest relevance (Ziebertz, 2007). This means that a much more open and pluralistic world view is dominant in Germany rather than dogmatic or limited concepts. However, as stated by the 'Religionsmonitor 2008', religious commands have low impact on young adults' every day life (they were relevant only for $13 \%$ of individuals $18-29$ years of age) (Ziebertz, 2007). Although religious commands are not identical with ethical norms, in this study only $22 \%$ of the students stated they oriented themselves with ethical norms. But one can be sure that they do have some ethical commitments, as can be seen by the high appreciation of Conscious interactions with others, environment, and Compassion / Generosity.

Finally, this brings us back to the core question of what spirituality might be for adolescents. There are numerous attempts to operationalize the multi-shaded concepts of religiosity and spirituality, and to make the 'un-measurable' measurable. For example, Tanyi globally defined spirituality as humans' search for meaning in life, while religion involves an organized entity with rituals and practices about a higher power or God (Tanyi, 2002). 
However, it seems that most adolescents will not rely on this 'organized entity'. Pargament defined spirituality as the "search for the holy" (Pargament, 1999). By contrast, the adolescents investigated in our study were not really in search for something holy, at least not within the context of organized religiosity.

Hay and Nye outlined awareness-sensing as an important category of children's spiritual sensitivity (Hay \& Nye, 2006), which involves a person attending to the 'here-andnow' of experience in moments of stillness and concentration. This aspect of spirituality is implicitly addressed with item s13 (aspiring to broad awareness) and s12 (aspiring to beauty and goodness), which are, however, interconnected with aspiring to insight and truth (s11), and adolescents' trying to develop wisdom (S10). These items made up the scale Aspiring Beauty / Wisdom. This unique aspect of wondering awe and awareness (s12 and s13) was rated very high particularly by adolescents with a spiritual attitude (R-S+ and $\mathrm{R}+\mathrm{S}+$ ), but was of relevance even for R-S- individuals.

Another attempt to define spirituality, as found in modern nurse theorists' ideas, differentiates five main topics, i.e., meaning, values, transcendence, connecting and becoming (Martsolf \& Mickley, 1998). Particularly the connecting domain (i.e., increased awareness of a connection with self, others, God/Spirit/Divine, and nature) is related to our scales Conscious interaction and Compassion / Generosity, which were of strong relevance for both female and male adolescents. One may interpret the main scale Conscious interaction with its two sub-constructs as secular humanism. All other domains, particularly 'meaning' (i.e., significance of life; making sense of situations; deriving purpose) and 'becoming' (i.e., an unfolding of life that demands reflection and experience), are actually not of significant importance but may develop during the adolescents' course of life as indicated in Figure 1. This development in terms of 'becoming' has to be encouraged and attended by parents, teachers, pastors, etc.

Although stated exclusively for children in public kindergartens, Sagberg's demand (Sagberg, 2008) is of relevance also for adolescents: "Nurturing children's predisposition as spiritual beings is clearly a matter of cultural learning, a matter of being-in-the-worlds, of situated learning, and many other insights into being and becoming human. The concept of spirituality connects these insights to the basic question: 'What is it to be me?'"

This process is an implicit task of an ever changing society. There must be a reason to develop as a responsible and considerate individual, to act consciously and compassionately to become human. Meaning in life is what matters. Meaningfulness is one of three core components of Antonovsky's 'Sense of Coherence'; it means that things are really worth it and that there is good reason to care about what happens (Antonovsky, 1987). This meaning is regarded as most important because if there is no reason to live and confront challenges, there will be no motivation to comprehend and manage life. This is what 'becoming' means.

Children and adolescents should have the chance to develop to adults as relational and moral beings, with a responsibility towards environment, economy, and society. As relevant elements in a more holistic use of spirituality in education, Sagberg mentioned: "Nurturing children's predisposition for meaning and relational consciousness, finding sources to the survival of human dignity, and developing a hope education" (Sagberg, 2008).

Europe's society today is obviously in a process of change, and this may affect adolescents' religiosity and spirituality, and we can not exclude the possibility that Western society is destructive to adolescents' formal aspects of spirituality (i.e. Religious orientation). However, it is obvious that the non-formal aspects of spirituality in terms of relational consciousness are vital, particularly secular humanism (i.e., Conscious interactions, Compassion / Generosity) and existentialistic awareness (i.e., Aspiring Beauty / Wisdom). Consequently, as central themes to a caring and wise education with a healthy evolution of consciousness as central focus, Gidley suggested that "an educational integration of love and reverence, with life-giving conceptual imagination and creative multi-modal methods (...) 
lays a strong foundation for the emergence of post-formal, integral consciousness" (Gidley, 2007). This 'becoming' of adults as conscious, respectful, and caring individuals is essential and it is a challenging task.

\section{Notes on contributors}

Arndt Büssing, MD, is a medical doctor and research professor at the Center for Integrative Medicine of the University Witten/Herdecke, Germany. He has published several research articles on spirituality and coping with chronic illness.

Axel Föller-Mancini, MEd is a teacher, research associate at the Center for Integrative Medicine of the University Witten/Herdecke, Germany, and has a teaching assignment at the Alanus University of Arts and Social Sciences in Alfter, Germany (Faculty of Education).

Jennifer Gidley, $\mathrm{PhD}$, is a psychologist, educator and research fellow in globalization and culture, Global Cities Research Institute, RMIT University, Melbourne, Australia. She has published widely in educational and youth futures and global socio-cultural change. She is President of the World Futures Studies Federation (2009-2013).

Peter Heusser, MD, MME, is a medical doctor and head of the Chair of Theory in Medicine, Integrative and Anthroposophic Medicine, Center for Integrative Medicine, University Witten/Herdecke, Germany. He has published on medical anthropology, Anthroposophic Medicine, quality of life in cancer patients, and spirituality in medicine.

\section{Acknowledgements:}

We are grateful to all the teachers who encouraged their students to fill in the questionnaires, particularly Britta Lehmann, Schwerte, for her encouraging support.

\section{References}

Antonovsky A. (1987) Unraveling the mystery of health. How people manage stress and stay well (San Francisco, London, Jossey-Bass).

Bouma G. (2006) Australian Soul: Religion and Spirituality in the 21st Century (Cambridge, Buschmann, G. (2001) Jugendkultur „Techno" - Säkularisierte Religiosität in der Postmoderne?, International Journal of Practical Theology, 5, 184-204.

Büssing, A. (2006a) Die Bodhisattva-Haltung - Zuwendung zum anderen [The Bodhisattva attitude - Turning to the other], Transpersonale Psychologie und Psychotherapie, 12, 60-70.

Büssing, A.: (2006b) „Spiritualität" - Worüber reden wir?, in: A. Büssing et al. (Eds.)

Spiritualität, Krankheit und Heilung - Bedeutung und Ausdrucksformen der

Spiritualität in der Medizin. (Frankfurt, VAS - Verlag für Akademische Schriften), 1124.

Büssing, A. (2009) Aspects of spirituality, God images, and the 'self-centredness' in 17 year old adolescents attending religious education at high-school, Research on Steiner Education, 1, accepted.

Büssing, A.: (2010) Die Bedeutung von Religiosität und Spiritualität für chronisch Kranke, in: F. Balck et al. (Eds.) Die Bedeutung von Religion für die Gesundheit. KonzepteBefunde - Erklärungsansätze (Weinheim, Juventa Verlag), accepted for publication.

Büssing, A., Abu-Hassan, W. M., Matthiessen, P. F., Ostermann, T. (2007a) Spirituality, religiosity, and dealing with illness in Arabic and German patients, Saudi Med J, 28, 933-942. 
Büssing, A., Fischer, J., Haller, A., Ostermann, T., Matthiessen, P. F. (2009a) Validation of the Brief Multidimensional Life Satisfaction Scale in patients with chronic diseases, Eur J Med Res, 14, 171-177.

Büssing, A., Fischer, J., Ostermann T, Matthiesen P.F. (2008) Reliance on God's help, depression and fatigue in female cancer patients, Int J Psychiatry Med, 38, 357-372.

Büssing, A., Michalsen, A., Balzat, H. J., Grünther, R. A., Ostermann, T., Neugebauer, E. A. et al. (2009b) Are spirituality and religiosity resources for patients with chronic pain conditions?, Pain Med, 10, 327-339.

Büssing, A., Ostermann, T., Matthiessen, P. F. (2005a) The Role of Religion and Spirituality in Medical Patients in Germany, Journal of Religion and Health, 44, 321-340.

Büssing, A., Ostermann, T., Matthiessen, P. F. (2007b) Distinct expressions of vital spirituality. The ASP questionnaire as an explorative research tool, Journal of Religion and Health, 46, 267-286.

Büssing, A., Ostermann, T.: (2004) Caritas und ihre neuen Dimensionen: Spiritualität und Krankheit. in: M. Patzek (Ed.) Caritas plus. Qualität hat einen Namen (Kevelaer, Butzon \& Bercker), 110-133.

Büssing A, Ostermann T, Glöckler M, Matthiessen PF. (2006) Spiritualität, Krankheit und Heilung - Bedeutung und Ausdrucksformen der Spiritualität in der Medizin (Frankfurt, VAS - Verlag für Akademische Schriften).

Büssing, A., Ostermann, T., Koenig, H. G. (2007c) Relevance of religion and spirituality in German patients with chronic diseases, Int J Psychiatry Med, 37, 39-57.

Büssing, A., Ostermann, T., Matthiessen, P. F. (2005b) Role of religion and spirituality in medical patients: confirmatory results with the SpREUK questionnaire, Health Qual Life Outcomes, 3, 1-10.

Engebretson, K. (2002) Expressions of religiosity and spirituality among Australian 14 year olds, International Journal of Children's Spirituality, 7, 57-72.

Engebretson, K. (2004) Teenage boys, spirituality and religion, International Journal of Children's Spirituality, 9, 263-278.

Engebretson, K. (2006) Identity, masculinity and spirituality: a study of Australian teenage boys, Journal of Youth Studies, 9, 91-110.

Gidley, J.: (2002) Global Youth Culture: A Transdisciplinary Perspective, in: J. Gidley \& S. Inayatullah (Eds.) Youth Futures: Comparative Research and Transformative Visions (Westport, Connecticut, Praeger), 3-18.

Gidley, J. (2005) Giving Hope back to our Young People: Creating a New Spiritual Mythology for Western Culture, Journal of Futures Studies: Epistemology, Methods, Applied and Alternative Futures, 9, 17-30.

Gidley, J. M. (2007) Educational imperatives of the evolution of consciousness: the integral visions of Rudolf Steiner and Ken Wilber, International Journal of Children's Spirituality, 12, 117-135.

Hay, D., Nye, R.: (2006) The Spirit of the Child, (London, Jessica Kingsley Publishers),

Helsper W, Ullrich H, Stelmaszyk B, Höblich D, Graßhoff G, Jung D. (2007) Autorität und Schule. Die empirische Rekonstruktion der Klassenlehrer-Schüler-Beziehung an Waldorfschulen. (Wiesbaden, VS Verlag für Sozialwissenschaften).

Huebner, E. S., Suldo, S., Valois, R. F., Drane, J. W., Zullig, K. (2004) Brief multidimensional students' life satisfaction scale: sex, race, and grade effects for a high school sample, Psychol Rep, 94, 351-356.

Hurrelmann K, Albert M. (2006) Jugend 2006. 15. Shell Jugendstudie: Eine pragmatische Generation unter Druck (Frankfurt, Fischer Taschebuch Verlag).

Jagodzinski, W., Dobbelaer, K. (1993) Der Wandel kirchlicher Religiosität in Westeuropa, Kölner Zeitschrift für Soziologie und Sozialpsychologie, Sonderheft 33, 68-91.

Koenot J. (1997) Hungry for Heaven. Rockmusik, Kultur und Religion (Düsseldorf, Patmos). 
Martsolf, D. S., Mickley, J. R. (1998) The concept of spirituality in nursing theories: differing world-views and extent of focus., Journal of Advanced Nursing, 27, 294-303.

Molz, M., Gidley, J. (2008) A transversal dialogue on integral education and planetary consciousness: Markus Molz speaks with Jennifer Gidley, Integral Review: A Transdisciplinary and Transcultural Journal for New Thought, Research and Praxis, 4, 47-70.

Pargament, K. (1999) The Psychology of Religion and Spirituality? Yes and No, The International Journal for the Psychology of Religion, 9, 3-16.

Sagberg, S. (2008) Children's spirituality with particular reference to a Norwegioan context: some hermeneutical reflections., International Journal of Children's Spirituality, 13, $355-370$.

Tacey D. (2003) The Spirituality Revolution: the Emergence of Contemporary Spirituality (Sidney,

Tanyi, R. A. (2002) Nursing theory and concept development or analysis. Towards clarification of the meaning of spirituality., Journal of Advances Nursing, 39, 500-509.

Underwood, L. G., Teresi, J. A. (2002) The Daily Spiritual Experience Scale: Development, Theoretical Description, Reliability, Exploratory Factor Analysis, and Preliminary Construct Validity Using Health-Related Data, Annals of Behavioral Medicine, 24, 2233.

Wintersgill, B. (2008) Teenagers' perception of spirituality - a research report, International Journal of Children's Spirituality, 13, 371-378.

Ziebertz, H.-G.: (2006) Germany: Belief in the Idea of a higher Reality., in: H.-G. Ziebertz \& W. K. Kay (Eds.) Youth in Europe II. An international empirical study about religiosity (Berlin, LIT Verlag), 58-80.

Ziebertz, H.-G.: (2007) Gibt es einen Trasierungsbruch. Befunde zur Religiosität der jungen Generation., in: Berteslmann Stiftung (Ed.) Religionsmonitor 2008 (Gütersloh, Berteslmann Stiftung), 44-53.

Zinnecker J. (1986) Jugendkulturen 1945-1985 (Opladen, Leske und Budrich).

Zullig, K. J., Huebner, E. S., Gilman, R., Patton, J. M., Murray, K. A. (2005) Validation of the brief multidimensional students' life satisfaction scale among college students, $\mathrm{Am} J$ Health Behav, 29, 206-214. 
Table 1. Demographic and psychometric data of 254 adolescents

\begin{tabular}{|c|c|c|c|}
\hline & $\begin{array}{c}\text { Females } \\
(51 \%)\end{array}$ & $\begin{array}{l}\text { Males } \\
(49 \%)\end{array}$ & $\begin{array}{c}\text { Significance } \\
p\end{array}$ \\
\hline Mean age (years) & $16.5 \pm 0.7$ & $16.6 \pm 0.7$ & n.s. $* *$ \\
\hline \multicolumn{4}{|l|}{ Family status (\%) } \\
\hline Living with both parents & 65 & 80 & $048 *$ \\
\hline living with mother & 26 & 18 & \\
\hline living with father & 5 & 2 & \\
\hline living with others & 4 & 0 & \\
\hline \multicolumn{4}{|l|}{ Denomination (\%) } \\
\hline Catholic & 56 & 62 & n.s. * \\
\hline Protestant & 36 & 28 & \\
\hline Other & 2 & 2 & \\
\hline none & 6 & 8 & \\
\hline \multicolumn{4}{|l|}{ SpR Self Categorization (\%) } \\
\hline $\mathrm{R}+\mathrm{S}+$ & 6 & 7 & $.067 *$ \\
\hline $\mathrm{R}+\mathrm{S}-$ & 27 & 14 & \\
\hline R-S+ & 6 & 6 & \\
\hline R-S- & 60 & 74 & \\
\hline \multicolumn{4}{|c|}{ Number of books in household (\%) } \\
\hline About 100 books & 23 & 18 & n.s. * \\
\hline $100-500$ books & 56 & 61 & \\
\hline$>500$ books & 21 & 21 & \\
\hline \multicolumn{4}{|l|}{ 'Self-centeredness' (\%) } \\
\hline No & 43 & 34 & $.031 *$ \\
\hline Unsure & 21 & 14 & \\
\hline Yes & 35 & 52 & \\
\hline Life Satisfaction (BMLSS) & $76.7 \pm 14.4$ & $77.6 \pm 12.0$ & n.s. $* *$ \\
\hline
\end{tabular}

* Chi2 test; ** ANOVA 
Table 2. Factor analysis of ASP questionnaire Version 2.1

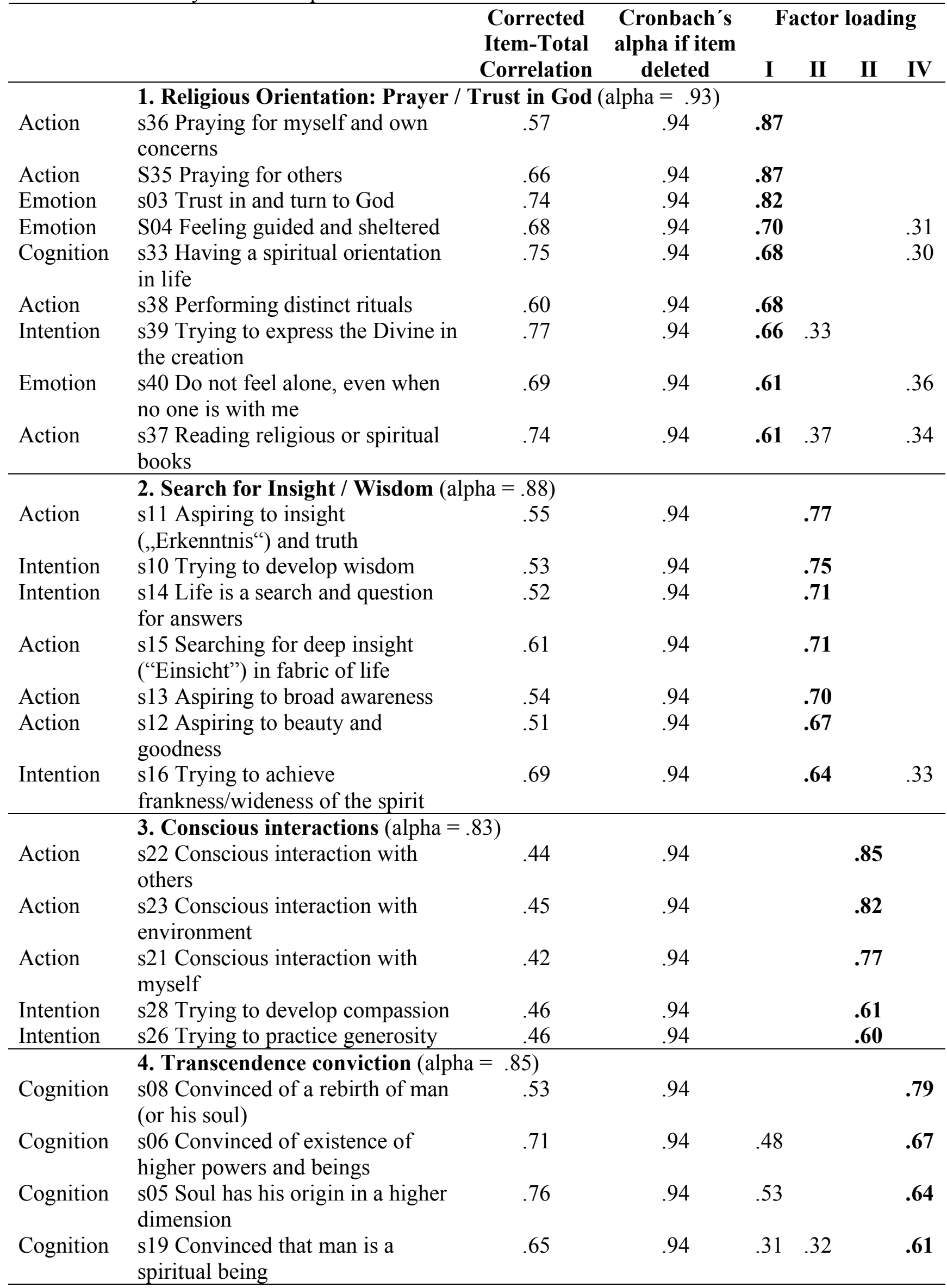


Cronbach's alpha $=.940, \mathrm{n}=1.191$; Kaiser-Meyer-Olkin measure $=.943$; Principal Component Analysis; Varimax Rotation with Kaiser Normalization (rotation converged in 6 Iterations); $64.6 \%$ explained variance; Factor loadings $<.3$ are not depicted. 